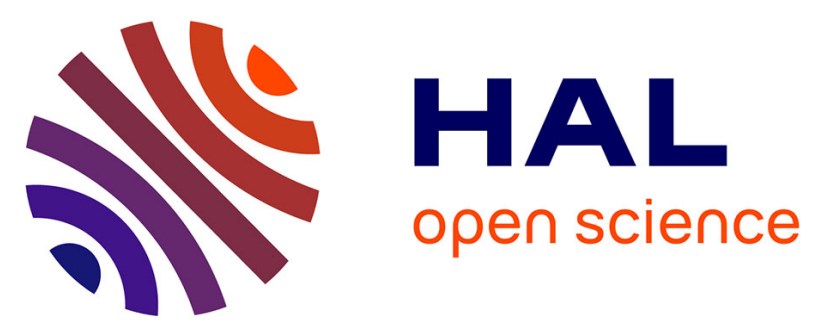

\title{
A Hitchhiker's guide to Mediterranean marina travel for alien species
}

\author{
Aylin Ulman, Jasmine Ferrario, Aitor Forcada, Christos Arvanitidis, Anna \\ Occhipinti-Ambrogi, Agnese Marchini
}

\section{To cite this version:}

Aylin Ulman, Jasmine Ferrario, Aitor Forcada, Christos Arvanitidis, Anna Occhipinti-Ambrogi, et al.. A Hitchhiker's guide to Mediterranean marina travel for alien species. Journal of Environmental Management, 2019, 241, pp.328 - 339. 10.1016/j.jenvman.2019.04.011 . hal-03484509

\author{
HAL Id: hal-03484509 \\ https://hal.science/hal-03484509
}

Submitted on 20 Dec 2021

HAL is a multi-disciplinary open access archive for the deposit and dissemination of scientific research documents, whether they are published or not. The documents may come from teaching and research institutions in France or abroad, or from public or private research centers.
L'archive ouverte pluridisciplinaire HAL, est destinée au dépôt et à la diffusion de documents scientifiques de niveau recherche, publiés ou non, émanant des établissements d'enseignement et de recherche français ou étrangers, des laboratoires publics ou privés.

\section{다)(1) $(5$}

Distributed under a Creative Commons Attribution - NonCommerciall 4.0 International 


\section{A HITCHHIKER'S GUIDE TO MEDITERRANEAN MARINA TRAVEL FOR ALIEN SPECIES}

Aylin Ulman ${ }^{1,2,3}$, Jasmine Ferrario ${ }^{1}$, Aitor Forcada ${ }^{4}$, Christos Arvanitidis ${ }^{3}$, Anna Occhipinti-Ambrogi $^{1}$ and Agnese Marchini $1^{*}$

${ }^{1}$ Department of Earth and Environmental Sciences, University of Pavia, Pavia, Italy

2Sorbonne Université, CNRS, Laboratoire d'Ecogéochimie des Environnements Benthiques, LECOB, Banyuls-sur-Mer, France

${ }^{3}$ Institute of Marine Biology, Biotechnology and Aquaculture, Hellenic Centre of Marine Research, Thalassokosmos, Heraklion, 71003, Crete, Greece

${ }^{4}$ Department of Marine Sciences and Applied Biology, University of Alicante, Spain

*Corresponding author email aylinh.ulman@unipv.it at Via S. Epifanio, 14, Pavia, Italy 


\section{Introduction}

The seas are currently inundated with many stressors such as overharvesting, eutrophication and pollution, physical alteration of natural habitats, climate change and invasive species which, combined, are negatively affecting both ecosystem structure and function (US National Research Council, 1995; Worm et al., 2006; Jackson, 2008). While many stressors, such as overfishing, have left much of the Mediterranean Sea barren (Guidetti et al., 2014), new species are constantly finding their way into the basin, and some of their preferred habitats are teeming with this 'foreign' life. While few of these new migrants have favourable effects on the economy, most are perceived negatively and are often considered as a form of biological pollution (Olenin, Minchin \& Daunys, 2007).

The Mediterranean is the most prevalent place in the world both for recreational boating (Cappato et al., 2011) and for marine bioinvasions, hosting between 700 to 1000 marine non-indigenous species (hereafter referred to as NIS; Galil et al., 2015; Katsanevakis et al., 2014). The definition of NIS used here is (European Environment Agency, 2012): "An organism introduced outside its natural past or present distribution range by human agency, either directly or indirectly". Thus, some kind of proof must be presented to support of that these new arrivals are indeed assisted by human activity.

Marinas, especially in the Mediterranean, have generally gone overlooked as source localities for NIS, due to (erroneous) perceptions about the effectiveness of antifouling paints (Minchin \& Gollasch, 2003), despite recent global research demonstrating marinas as important hubs both for primary introduction and for secondary stepping-stone invasion events (Ashton, Davidson \& Ruiz, 2014; Clarke-Murray et al., 2011; Ferrario et al., 2017).

'Pathways' facilitating transfers of species, such as shipping, aquaculture, and artificial canals are generally responsible for primary introduction events of NIS, and one pathway may have several associated 'vectors' for secondary transfers. For example, the principal vectors associated with the shipping pathway can be 'ballast water', 'ballast tank' (Casas-Monroy et al., 2011), or part of the 'biofouling'. Biofouling is the colonization of algae, plants and/or animals of submerged artificial surfaces, such as piers and boats. 
Currently, only two pathways or vectors are under(going) regulation in Europe: direct transfers via aquaculture as of 2007 (\#708/2007; EUROPA 2007), and ballast water as of September 2017 (Ballast Water Management Convention; www.imo.org). Thus, the transfer of NIS via biofouling is now considered the largest unregulated vector for NIS introductions (Clarke-Murray et al., 2011; Zabin et al., 2014). Another major vector of concern in the Mediterranean is the man-made Suez Canal, discussed in detail by Galil et al. (2017), which likely helps expedite several other vectors of secondary spread such as ballast water and biofouling, due to reduced shipping travel times, thus improving survival opportunities for non-indigenous biota..

Boats of any type, size or class can have biofouling attached to their hulls (Carlton 2003). Thus, recreational marinas emerge as a natural laboratories to conduct large-scale studies on NIS. These new migrants have been arriving more frequently especially to the Eastern Mediterranean in recent decade (Galil et al., 2018); from the Levantine marinas they can hitch a ride wherever the wind or gas takes their host. Once new marine species are established in a locality, eradication is nearly impossible, thus prevention is universally considered the best management option for NIS (Ojaveer et al., 2014; Olenin et al., 2016).

Bioinvasions are now a common component of global change, and many invaders flourish in artificial habitats. Artificial structures can be fashioned from either man-made or natural materials but are specifically designed for human purposes (Mineur et al., 2012), thus all aspects of marinas are considered artificial structures. Fouling communities on artificial substrates have been shown to host NIS different from their natural counterparts (Connell, 2000; Megina et al., 2016). This is likely because these structures are usually located in sheltered habitats, with modified water circulation (Floerl \& Inglis, 2003), and home to intensive human traffic and vessel movement (Callier et al., 2009), which can sometimes host complex fouling communities (Glasby et al., 2007; Tyrell \& Byers, 2007). In fact, in addition to NIS being shown to favour artificial substrates, increased habitat complexity resultant of biofouling has been shown to further exacerbate the establishment of additional fouling species (Marchini et al., 2015; Simkanin et al., 2017) as it can provide further habitat, food supplies and protected niche areas.

The successful establishment of NIS is thought to be reliant on combinations of both biotic and abiotic factors (Early \& Sax, 2014) but aspects of these factors fluctuate both spatially and temporally, thus each habitat has different underlying factors affecting settlement success. Firstly, there is the supply of new propagules to a marina from visiting vessels each hosting different fouling assemblages, i.e., propagule pressure (Lockwood et al., 2005; Wonham et al., 2005). Secondly, the 
biological traits of each NIS, such as species characteristics including dispersal techniques, nutrient accessibility and spatial requirements, are also contributing factors (Simberloff \& Von Holle, 1999; Cardeccia et al., 2018). Thirdly, there are the complex interactions between local environmental conditions (Colautti et al., 2006, Wonham et al., 2013) and species characteristics. All factors combined lead to a very complex matrix of possibilities for invasion success, and obviously, all probable factors cannot conceivably be concurrently tested. Here, environmental matching is explored to determine if similar environmental conditions (such as temperature and salinity) along with different aspects of marinas foster similar NIS.

Understanding some key underlying factors behind spatial distribution patterns of NIS communities in marinas can help clarify which factors contribute to settlement success (Clarke-Murray et al., 2014). This work aims to better understand the distribution of NIS in the Mediterranean, particularly pertaining to recreational marinas by exploring which abiotic factors convert certain marinas into bioinvasion 'magnets' thus affecting their NIS community patterns across larger scales. Here, we perform the first large-scale study of NIS across marina habitats spanning the Northern Mediterranean region in order to test: (a) Which abiotic factors of the marinas are found to influence total NIS richness marinas and (b) Which factors affect the multivariate structure of the NIS assemblages between marinas or groups of marinas. These results may help influence effective management strategies to help deter marine bioinvasions via the biofouling vector in the future.

\section{Methods}

\subsection{Study area}

The results from previous studies assessing NIS in Mediterranean marinas (See Tab. S1 for reference list) were combined to perform an extensive analysis of 50 Mediterranean marinas spanning seven countries along the northern rim of the Mediterranean Sea (Fig. 1 and S1).

\subsection{Marina sampling strategy}

This study collected macroinvertebrate taxa for identification. The samples were taken from submerged artificial substrates using a hand-held rigid net $(1 \mathrm{~mm}$ mesh size, surface area of $25 \times 20$ 
$\mathrm{cm})$, having one sharpened edge capable of dislodging well-cemented taxa such as barnacles and oysters from the substrate. This net was used to scrape the substrate over an area of approximately $0.23 \mathrm{~m}^{2}$ per sample. For the marinas formerly investigated by Ferrario et al. (2017), as well as the new material presented here (see "unpublished" records in Supp. Table 1), nine samples of biofouling were collected from each marina from the main docks or floating pontoons, covering all regions of the marina. Samples were preserved in $4 \%$ formalin solution and further transferred to ethanol for taxonomic identification.

For the marinas sampled in the Ulman et al. (2017) study, a 'modified' rapid assessment survey (RAS) (Pedersen et al., 2003; Cohen et al., 2005; Ashton et al., 2006) was adopted, with an expanded collection time of approximately 8 hours per marina, or until it was considered no additional species could be found. Marina samples were taken from the innermost, outermost and middle portions of the marina to ensure representative sampling. These samples were sorted according to taxa on-site, and then preserved in a 90\% ethanol solution, with ascidians as the exception (Ulman et al., 2017

\subsection{Statistical analyses}

\subsubsection{Total number of NIS (species richness) per marina response variable}

The total NIS per marina was calculated, after each species had their NIS status for the Mediterranean Sea verified (Clark \& Johnston, 2009) was used as the dependent variable which was tested against the abiotic factors explained below. The criteria used for evaluating the nonindigenous status was from Chapman \& Carlton (1991).

\subsubsection{Abiotic factors}

The factors included in this study were partially derived from: (a) Previous studies on the topic conducted elsewhere which found the same factors to be significant (Floerl \& Inglis, 2003; ClarkeMurray et al., 2014; Foster et al., 2016; Peters et al., 2017); (b) Our own personal observations and the corresponding hypotheses made during marina sampling and from interviews with local marina staff and boat owners. The abiotic factors tested here include environmental factors, marina specific features and proximity to major vectors, and are highlighted in bold text below.

\subsubsection{Environmental factors}

Salinity was measured at each marina using a refractometer (Aquafauna Model \#8408). In brackish seas or along corridors connecting two water bodies, salinity is considered the most important factor for limiting the range or niche of species (Cognetti \& Maltagliati, 2000). In marinas that receive 
relevant freshwater inputs, settlement and reproduction of euryhaline species will be favoured (Floerl \& Inglis, 2003). Proximity to freshwater source was codified as a binary variable (yes/no) and was deemed proximate if a source (river, spring or lagoon) was within a $5 \mathrm{~km}$ radius from the marina and therefore has the potential to affect the marina waters. We hypothesised that higher nutrient input due to riverine discharge may positively affect abundance and growth rates of fouling assemblages of selected taxa, or alternatively, lower salinities would surpass the threshold tolerance of other taxa.

Temperature was measured using a thermometer for aquaria, and the water was collected from $1 \mathrm{~m}$ depth to exclude the immediate warmer surface temperature layer. Temperature was found in other studies to be a good predictor of NIS richness, since this has a direct influence on reproductive success, i.e., most species have a minimum temperature requirement needed to trigger reproductive events (Brock-Morgan, 2010; Gallardo \& Aldridge, 2013); it is also the only factor here that accounts for the seasonality of different sampling dates.

General primary productivity was derived from a study that averaged primary productivity levels in $\mathrm{g}$ $\mathrm{C} \mathrm{m}^{-3}$ from 2000-2009 using satellite data (Colella et al., 2016). Chlorophyll levels (a proxy of phytoplankton biomass) have been described as one of the most important variables for successful NIS establishment (Tyberghein et al., 2012).

The Köppen-Geiger climate classification (Peel et al., 2007) was used to test if similar climates had an influence on NIS richness; climate match is considered a potential factor as species have specific niche habitat requirements (Bax et al, 2003). The Mediterranean was split into ten biogeographic sectors following the subdivision proposed by Bianchi \& Morri (2000); we added an additional $11^{\text {th }}$ sector here to incorporate the Istanbul region (the Bosphorus Strait and Marmara Sea). The designations of these sectors account for the evolutionary histories of the areas and their inventories combined with climatic variations.

\subsubsection{Marina factors}

A higher number of berths has been indicated elsewhere to correlate to higher NIS richness (Nall et al., 2015; Ros et al., 2013), as it can be a proxy for increased vessel traffic, and hence higher propagule pressure (Occhipinti-Ambrogi, 2007). Total pier length was measured in $\mathrm{km}$ and marina area was measured in $\mathrm{km}^{2}$ (Google Earth Pro, 2016) as NIS have repeatedly demonstrated better success in artificial habitats over natural ones (Airoldi et al., 2015; Glasby et al., 2007; Jiminez et al., 
2018; Simkanin et al., 2017). Therefore, additional marina habitat could promote more introduction events, and larger marina size has been shown to influence the establishment of NIS (Clark \& Johnston 2009; Clark \& Johnston, 2005; Connell \& Glasby, 1999; Peters et al., 2017). Presence of floating pontoons was codified as a binary variable (yes/no); the shallower portions of artificial substrates have shown to host higher NIS than their deeper counterparts (Dafforn et al., 2009), since they are separated from the seafloor, these habitats escape most predation (Bishop et al., 2015b; Connell, 2001; Connell \& Glasby, 1999; Simkanin et al., 2017). Finally, marina opening length width was measured in km (Google Earth Pro, 2016); a partially-enclosed marina with a smaller opening length has shown to positively influence both the quantity and frequency of recruitment events due to the confinement of larval dispersal (Brock-Morgan, 2010; Floerl \& Inglis, 2003; Foster et al., 2016).

Proximity to aquaculture sites was codified as a binary variable (yes/no); an internet search was performed using the marina name, and also the names of the nearby towns, in combination with the terms "aquaculture", "shellfish" or "fish farm" in the native language, and deemed proximate if $<5$ $\mathrm{km}$ in distance from the marina. Many fish farm localities stemmed from the Trujillo et al. (2012) report, and many of the Sicilian fish farms were from the Popescu (2010) source. Aquaculture facilities can facilitate both the availability and establishment of NIS by direct introduction for culturing, which can then develop self-sustaining populations nearby, or indirectly by hitchhiking on associated species on the cultured biota as epibionts (Naylor et al., 2001; Ruesink et al., 2005). In the EU, the introduction of NIS through aquaculture is controlled by Regulation 708/2007 and 1143/2014 which require specific permission to introduce a new species, but this does not protect from epibionts and associated mobile organisms (European Commission, 2016).

Proximity to commercial harbours was codified as a binary variable (yes/no) and was deemed proximate if a harbour was $<5 \mathrm{~km}$ away. Ports are understood to be the main entry point for NIS (Gallardo \& Aldridge, 2013; Minchin et al., 2006; Occhipinti-Ambrogi, 2007). This is because NIS can travel to ports via the major pathway being shipping and its two major vectors of transmission: in ballast water or as part of the biofouling (Seebens et al., 2016). Thus, harbours along with marinas have been advised as focal areas for the early detection of NIS (Lehtiniemi et al., 2015).

Presence of a shipyard in the marina was codified as a binary variable (yes/no); boats generally get hauled-out of the water for annual maintenance (including cleaning, and the application of new antifouling paint) prior to their commencement of the tourist season. Recent laws enacted in most marinas now ensure that the biofouling waste removed from the hulls is disposed of separately (i.e., 
not directly into the marina waters themselves), but we have directly observed that these regulations are not always respected. Although the success of propagules released after cleaning operations has yet to be assessed (Verling et al., 2005), here we assume that presence of shipyard can affect propagule pressure and, ultimately, NIS richness in a marina.

Each marina's distance to the Suez Canal was calculated considering the shortest navigational route from the northern entrance of the canal in $\mathrm{km}$. As the Suez Canal is an artificially created waterway, Indo-Pacific species traveling through here are considered NIS, either by natural establishment or through human-mediation. Over half of the multicellular NIS thriving in the Mediterranean more than likely has entered via this canal, which should be considered the major vector for marine introductions in the Mediterranean (Galil et al., 2015; Galil et al., 2018), hence we assume that those marinas in closer proximity to the Suez Canal may host more NIS.

\subsubsection{Outline of statistical analyses applied to data}

\subsubsection{Univariate analysis}

The total NIS richness per marina, tested against the series of abiotic factors (Fig. 2), were used to test the null hypothesis that abiotic factors have no correlation to NIS richness in Mediterranean marinas. The nature of the relationships between total NIS richness per marina and the above mentioned abiotic factors considered (as explanatory variables) were visualized using scatterplots (for continuous variables) and boxplots (for categorical variables). Total NIS richness found in each marina was modelled as a function of the abiotic factors by means of generalized linear models (Fig. 2, GLMs) (McCullagh \& Nelder, 1983) in order to identify which of these influence the increment of NIS. GLMs are an extension of linear models allowing the incorporation of non-normal distributions of the response variable and transformations of the dependent variables to linearity (McCullagh \& Nelder, 1983). Using the total number of NIS as a response variable, for this type of count data with non-negative values, a GLM with log link function and Poisson error distribution is recommended (McCullagh \& Nelder, 1983). Data exploration was applied following Zuur et al. (2010). The presence of outliers were investigated using Cleveland dotplots, meanwhile collinearity was assessed using multi-panel scatterplots, Pearson correlation coefficients and variance inflation factors (VIF). Finally, the initial model applied contained all abiotic factors except for 'Total pier length' because this factor was found to be highly collinear with the 'Number of berths' factor. Therefore, the general model used was: 
$\log \left(\mu_{i}\right)=\log \left(E\left(U_{i}\right)\right)$

$=B_{1}+b_{2} \times$ Salinity $_{i}+b_{3} \times$ Temperature $_{i}+B_{4} \times$ PrimaryProductivity $_{i}+B_{5} \times$ Area $_{i}+B_{6} \times$ NumberBerths $_{i}+$

$b_{7} \times$ OpeningLength $_{i}+b_{8} \times$ DistanceSuezCanal $_{i}+b_{9} \times$ ProximityFreshwater $_{i}+b_{10} \times$ PresenceShipyard $_{i}+$

$B_{11} \times V_{\text {VicinityAquaculture }}+B_{12} \times$ VicinityCommercialHarbours $_{i}+b_{13} \times$ PresencePontoons $_{i}+$

$B_{14} \times$ BiogeographicSector $_{i}+B_{15} \times$ ClimateType $_{i}$

Where $\mu_{i}$ is the expected number of NIS and $B_{t}$ is the parameter set relating the dependent variables to the response, using a log link function and a Poisson distribution for the response variable. Backward selection using the Akaike Information Criterion (AIC; Akaike, 1974) was used to find the optimal model. The AIC determines between adding or excluding each variable, creating a balance between the variability explained by each factor and the degrees of freedom introduced in the model (Akaike, 1974). Model validation was applied on the optimal model to verify the underlying assumptions (Zuur et al., 2013). Specifically, Pearson residuals were plotted versus fitted values, and also against each covariate in the model and those covariates not in the model to investigate patterns. Additionally, both over-dispersion and under-dispersion were assessed, and Cook's distance value was used to check the presence of outliers in the model. All these analyses were conducted by R statistical computing software (R Core Team, 2016).

\subsubsection{Multivariate analysis}

The multivariate structure of the entire assemblage of NIS found per marina and the series of abiotic factors were used (Fig. 2) to test the null hypothesis that abiotic factors are not correlated to NIS distribution similarity patterns amongst Mediterranean marinas. Multivariate techniques suited for ecological data were used allowing for the investigation of each individual NIS' contribution to the assemblage found within each of the marinas studied. Thus, combined non-metric multidimensional scaling (nMDS) with hierarchical cluster (Clarke, 1993; Clarke \& Warwick, 2001) were selected, in order to explore the multivariate pattern of the NIS assemblages in the Mediterranean marinas studied and, finally, to assess the differences of the composition of the NIS assemblages within each marina.

For all the multivariate techniques used, the similarity pattern between NIS assemblages were calculated using the Bray-Curtis resemblance coefficient, based on presence/absence data of NIS (Bray \& Curtis, 1957). Normalized Euclidean distance was used to explore the multivariate pattern of the abiotic variables (Clarke \& Warwick, 2001). 
Specifically, to explore the most closely associated abiotic factors with the multivariate structure of NIS, first the BEST, then LINKTREE routines were performed using PRIMER v6 software (Clarke \& Gorley, 2006). A first assessment of the relationships between the multivariate structure of NIS and abiotic factors were provided by BEST, which were then used to select the subset of abiotic factors that best correlated with the multivariate assemblage patterns of NIS. In order to carry out a stepwise search of each possible combination of abiotic factors, the BVSTEP procedure was run using Spearman's coefficient as a rank correlation method (Kendall, 1970). Subsequently, a global BEST match permutation test (using 999 permutations) was run to test the degree of association between the multivariate structure of NIS and the subset of abiotic factors selected. All subsets of variables strongly collinear (with Pearson's correlation coefficient values $>0.95$ or $<-0.95$ ) were reduced to a single representative in the BEST run (Clarke \& Warwick, 2001), thus removing one factor (total pier length) from the strongly collinear pair (number of berths) considered to have a lesser influence than the other. Next, these abiotic factors selected by BEST (i.e., which strongly corelated with multivariate structure of NIS) were included as the independent (explanatory) variables in the subsequent LINKTREE procedure (De'ath, 2002). LINKTREE is a non-parametric multivariate form of classification and regression technique that works by constructing a hierarchical tree through successive dichotomies of sets of observations (marinas) using divisive clustering. Each division is characterized by the most influential variables, which can be a single or combination of variables (abiotic factors), and the procedure is repeated until all sites are sorted into groups sharing the same underlying factors and ranges of values that seem responsible for distinguishing each different internal NIS assemblage grouping. The LINKTREE procedure is capable of distinguishing that an abiotic factor is important for the internal assemblage structuring of one group of samples, but not for another, even for groups with similar ranges of values.

For the overall multivariate testing technique, similarities between NIS assemblages were calculated using the Bray-Curtis similarity index, based on presence/absence data of NIS (Bray \& Curtis, 1957). For the previously described analyses, the similarity matrix of abiotic factors was calculated using “Normalized Euclidean distance” (Clarke \& Warwick, 2001).

The "similarity profile" permutation test (SIMPROF) (Clarke \& Gorley, 2006) was combined with hierarchical cluster and LINKTREE to validate the identification and interpretation of clusters. The $5 \%$ significance level was conventionally applied, and 1000 permutations were run to calculate the mean similarity profile, with 999 permutations to generate the null distribution of the departure statistic, $\pi$. Subsequently, the contribution of each NIS to internal-group similarity was assessed for the groups 
identified by SIMPROF in the cluster using the SIMPER (SIMilarity PERcentages) procedure (Clarke \& Warwick, 2001), identifying those NIS that are more important for each group of marinas.

\section{Results}

The full data-set containing the recorded NIS for each marina are presented in Appendix 1, S2.1-S2.4. The abiotic factors measured or assessed for each marina are presented in Tab. S3.1-S3.5 (Appendix 1). The total number of NIS found in each marina are presented both by number (Tab. 2) and by taxa in Fig. 3, which ranged from 2 in Villfranche-sur-Mer (France) and Alassio (Italy) to 27 NIS in Heraklion (Greece). The most widely distributed NIS are presented in Tab.3 and the SIMPER results showing similar taxa between marina groupings are shown in Appendix 1 S4.

\subsection{Qualitative analysis}

Generally, there was higher total NIS richness in the Eastern and Central Mediterranean than the Western Mediterranean. Overall, crustaceans, ascidians, bryozoans and polychaetes were the dominant taxa of NIS found in most marinas (Fig. 3). Additionally, there was a slightly higher number of NIS mollusc records in the Eastern Mediterranean, than in other regions, aside from a couple marinas near aquaculture localities in France. Records of non-indigenous porifera were mainly restricted to the Central and Eastern Mediterranean.

The most widespread NIS found in this study (Tab. 3) were Styela plicata (Lesueur, 1823), Hydroides elegans (Haswell, 1883), Amathia verticillata (delle Chiaje, 1822), Caprella scaura Templeton, 1836, Celleporaria brunnea (Hincks, 1884), and Paranthura japonica Richardson, 1909.

\subsection{Quantitative analysis}

\subsubsection{Univariate analyses on total NIS richness in marinas}

From the resulting relationships between the total NIS richness and the quantitative abiotic factors (Fig. 4a), it emerges that the significant factors (shown in bold) were: (a) Higher sea-surface water temperatures, (b) Number of berths and, (c) Proximity to the Suez Canal. Sea-surface water temperatures strongly influenced total NIS richness, although the pattern was not linear, since it positively correlated to total NIS richness when it ranged between $15^{\circ} \mathrm{C}$ and $23^{\circ} \mathrm{C}$ and again between $26^{\circ} \mathrm{C}$ and $30^{\circ} \mathrm{C}$, but negatively correlated when was between $24^{\circ} \mathrm{C}$ and $26^{\circ} \mathrm{C}$. The remaining factors 
showing no significant and weaker trends included salinities above 38 PSU, average primary productivity below $1 \mathrm{~g} \mathrm{C} \mathrm{m}^{-3}$, larger marina area and a larger marina opening width.

From the correlations obtained between NIS richness and the categorical qualitative abiotic factors (Fig. 4b), the significant factors (shown in bold from Fig. 4b) associated with higher total NIS richness in marinas were: (a) Proximity to aquaculture sites; (b) Proximity to commercial harbours; (c) Absence of floating pontoons; (d) Pertaining to biogeographic sector I (representing the marinas in Turkey and Cyprus); (e) Pertaining to climate type Bsh (hot semi-arid climate for Cyprus). Proximity to freshwater source and presence of shipyard sites showed no significant trend. However, pertaining to biogeographic sector K (Marmara Sea and the Bosphorus Strait pertaining to Istanbul), and to a lesser extent biogeographic sectors D (southern France and western Italy), along with pertaining to climate types Cfa and Csb showed a relationship towards lower NIS richness.

Regarding the GLM of the total NIS richness as a function of all the selected abiotic factors, the analysis of Pearson residuals confirmed the goodness-of-fit of the models on the factors, so no additional transformation was necessary for their inclusion. The optimal model selected in the backward AIC procedure resulted in a model that considered the following eight abiotic factors as explanatory variables: temperature, number of berths, distance to Suez Canal, proximity to aquaculture sites, proximity to commercial harbours, presence of floating pontoons, biogeographic sectors and climate type. This model explained $72.1 \%$ of the variance observed for the total number of NIS. From analysing the coefficients of each term in the model (Tab. 3), the total NIS richness seemed to have an exponentially positive trend in relation to temperature and number of berths, and was also positively related with marinas in closer proximity to the Suez Canal. The marinas which were closer to commercial harbours had (on average) a higher number of NIS. Surprisingly, it was also found that if marinas had floating pontoons present or were further from aquaculture sites they host a lower number of NIS. Ordering Bianchi and Morri's (2000) biogeographic sectors from high to low values in the total NIS richness resulted in Sector I (the Ionian Sea and South Aegean); B (Algeria and Southern Spain ); C (Balearic Sea to Tyrrhenian Sea); Sectors E (Northern Adriatic), D (Gulf of Lyon and Ligurian Sea), the lowest K (Marmara Sea and Bosphorus Strait). Lastly, the number of NIS was higher in marinas with a climate type Bsh (hot, semi-arid climate), and Bsk (temperate semi-arid climate) and lower if they have Csb or Cfa (temperate, without dry season).

\section{$\underline{3.3 \text { Multivariate analyses based on NIS assemblage structure }}$}

The nMDS analysis (Fig. 5), resulted in an unexpected combination of marinas sharing high similarities in their NIS assemblage compositions (over $50 \%$ ) and without significant differences 
between their NIS assemblage compositions (SIMPROF P>0.05), despite considerable geographical distances between them; Group ' $f$ ' is composed of marinas from Sicily (Marina Villa Igiea, Siracusa, Marzamemi, Marina di Ragusa, Porto La Cala, Licata Cala del Sole, Riposto Porto dell'Etna), Spain (Port Vell, Barcelona) and Malta (Grand Harbour), with S. plicata and A. verticillata each contributing $11 \%$ to total similarities. Similarly, group ' $g$ ' is composed of the three Greek marinas (Agios Nikolaos, Heraklion and Rhodes Mandraki), which also showed high similarities $(>50 \%)$ in their NIS communities without significant differences between them (SIMPROF P $>0.05$ ), but in this case, Rhodes is quite distant geographically from the other two marinas in Crete (over $450 \mathrm{~km}$ ), but less than $50 \mathrm{~km}$ from Marmaris in Turkey, which it showed to have no species in common with; for these Greek marinas, the characterising species were S. plicata, Symplegma brakenhielmi Michaelsen, 1904, Celleporaria vermiformis (Waters, 1909), B. pharaonis, P. magna, B. bairdi and H. elegans each contributing $10 \%$ to similarities.

Additionally, there are three groups of marinas that, while displaying lower NIS similarities (less than 35\%) within each group, had significant different NIS assemblages from the other marinas (S4); These groups are ' $a$ ' (Kalamiş, Ataköy and Piombino) with Amphibalanus eburneus (Gould, 1841), and Ficopomatus enigmaticus (Fauvel, 1923) each contributing 50\%; ' $b$ ' (Datça and Karpaz Gate and Famagusta, Turkey and Cyprus, respectively) which had B. pharaonis contributing 20.3\%, Microcosmus exasperatus Heller, 1878, Cerithium scabridum Philippi, 1848, Dendostrea folium Linnaeus, 1758, Pinctada imbricata (Gould, 1850) and Septifer cumingii Récluz, 1848, each contributing 7.5\%, Clavelina oblonga Herdman, 1880 and B. bairdi $7.2 \%$ and Herdmania momus (Savigny, 1816), Phallusia nigra Savigny, 1816, C. vermiformis and Ampithoe bizseli Özaydinli \& Coleman, 2012 each contributing 5.7\% to species similarities; and ' $i$ ' (Fethiye Ece and Finike, both in Turkey) with Diplosoma listerianum (Milne Edwards, 1841), S. plicata, S. brakenhielmi and $H$. dirampha each contributing $25 \%$ to total similarities.

The remaining groups identified by the SIMPROF test $(c, d, h)$, shared high similarities in their NIS assemblages in their groupings (47-56\%), and were significantly different from the other groups (ranging from 35-47\%), and are composed of a mix of marinas from several countries (Tab. S4 in Appendix 1). The NIS assemblage composition of marinas from France and Italy are grouped in ' $c$ ' and ' $d$ ', meanwhile marinas in group ' $h$ ' span across the Mediterranean from Spain, France, Italy, Malta and Turkey. Group ' $c$ ' had NIS influences from H. elegans 57\%, S. plicata 13.6\%, Ascidiella aspersa (Müller, 1776) 11.6\%, and C. brunnea contributing 9.7\%. Group ' $d$ ' has the following NIS contributing similarities: C. scaura and P. japonica (20.7\%), S. plicata and Tricellaria inopinata d'Hondt \& Occhipinti-Ambrogi, 1985 (13.5\%), laniropsis serricaudis Gurjanova, 1936 (9.1\%), Magallana gigas 
Thunberg, 1793 (6\%), H. elegans (5.5\%) and Arcuatula senhousia Benson, 1842 (5.3\%). Group ' $h$ ' had C. brunnea contributing $19 \%$, A. verticillata $15.9 \%$, H. elegans $15.2 \%$, S. plicata $13 \%$, C. scaura $12.8 \%$, P. japonica $8.9 \%$ and $H$. dirampha $6.5 \%$ to total similarities.

\subsection{Relationship between NIS assemblage structure and abiotic factors}

After all abiotic variables were tested for correlation with each other, all were found to be uncorrelated (Pearson's correlation coefficient $<0.95$ ) and therefore all were included in the successive BEST analysis to screen which combination(s) of factors better explain the multivariate patterns of NIS communities. The BEST results revealed that the following combinations of these six factors: (a) 'Sea-surface temperature'; (b) 'Average primary productivity'; (c) 'Pertain or not to Biogeographic region K'; (d) 'Proximity to commercial harbours'; (e) 'Proximity to Suez Canal' and, (f) Pertain or not to Climate type Bsh (hot semi-arid climate), were those correlated with the NIS assemblage structure (Rho $=0.597, p<0.001$ ), hence these factors were included for testing in the subsequent LINKTREE analysis (Fig. 6).

The results of the LINKTREE analysis (Fig. 6) show which of the above six main factors are deemed responsible for grouping marinas based on their internal NIS assemblages (based on the Bray-Curtis similarity index). The groups are ordered by highest differences from the others groups at the top, and the results first grouped Datça, Turkey as the most dissimilar from the other marinas, which was associated with its biogeographic sector and proximity to the Suez Canal, along with its mean very low primary productivity; and with the same dissimilarity of $90 \%$, all the French marinas along with Alassio, Italy (Italian Riviera adjacent to the French marinas) were grouped together according to their distance from the Suez, mean surface temperature $<21^{\circ} \mathrm{C}$ and primary productivity greater than $0.15 \mathrm{~g} \mathrm{C} \mathrm{m}^{-3}$. The next grouping split the two marinas in Istanbul together (Kalamiş and Ataköy by a dissimilarity value of $90 \%$ ), as their NIS assemblages differed from the other groups and linked to their distinct biogeographic region, which distinctively differed from the other marinas in salinity and geography, as they are situated on the Bosphorus Strait. Next, Famagusta and Karpaz Gate in Cyprus were grouped together with a $78 \%$ dissimilarity from the other groups, best explained by their proximity to the Suez Canal (465 and $530 \mathrm{~km}$, respectively) and distinct biogeographic region being hot arid and dry. Next, Finike and Fethiye in Turkey were separated from the rest (with a dissimilarity of $65 \%$ ) also linked to their relatively short distance from the Suez Canal. The next group differed from the other groups by $55 \%$ which included the marinas from the Venice Lagoon in the Adriatic Sea with a much higher average primary production of over $5 \mathrm{~g} \mathrm{C} \mathrm{m}^{-3}$. The next grouping had a dissimilarity of $41 \%$ and included Porto Rotondo in Sardinia (Italy) and Villefranche-sur-Mer in France, with average primary productivity $<3 \mathrm{~g} \mathrm{C} \mathrm{m}^{-3}$. The subsequent grouping contained Ischia and Sorrento 
in Italy (which are in very close proximity) with a much lower primary productivity of $<3 \mathrm{~g} \mathrm{C} \mathrm{m}^{-3}$. Successively, there was an interesting assortment of marinas from the Western Mediterranean from Barcelona extending to the Central Mediterranean to Siracusa, Sicily with a dissimilarity of $28 \%$ from the remainder groups and associated with their slightly higher primary productivity of $0.4 \mathrm{~g} \mathrm{C} \mathrm{m}^{-3}$. Lastly, the marinas of Sicily and Malta were grouped together and differing from the other groups by $32 \%$, with water temperatures $>24^{\circ} \mathrm{C}$ and greater distances from the Suez Canal of $>2400 \mathrm{~km}$.

\section{Discussion}

The thorough analysis of several major abiotic factors underlying the NIS richness and their distribution in recreational marinas of the Mediterranean applied in the framework of this study, provides evidence to understand the differences in emerging NIS patterns and to provide hypothesistesting knowledge for effective biofouling management in the Mediterranean Sea (Hopkins \& Forrest, 2008). The sampled marinas span the entire Northern Mediterranean basin and host from 2 to 27 NIS.

Factors contributing to NIS richness in marinas include proximity to aquaculture sites, and major ports (for the qualitative factors), as these are the other source areas for NIS introductions, thus demonstrating the importance of a major global vector for NIS transport (shipping as a pathway and ballast water or biofouling as vectors to transport species). The aquaculture area sampled here was in France (the Thau Lagoon surroundings) where more than likely several species arrived to nearby marinas of Port Camargue and Grand-Motte via the aquaculture vector (i.e., Aoroides longimerus Ren \& Zheng, 1996, Balanus trigonus Darwin, 1854, C. brunnea, P. japonica; Boudouresque et al., 2010). Additional contributing factors are the following: (a) Absence of floating pontoons, a counterintuitive result, especially when considering that most of the sampled marinas contained floating pontoons, contrasting previous research carried out in a non-Mediterranean context (Dafforn et al., 2009; Nall et al., 2015); (b) Climate type hot and dry (representing Cyprus, our most eastern sampling area); (c) Biogeographic sector I (representing southern Turkey and Cyprus); (d) Highest sea surface temperatures; (e) Higher number of berths, similarly to the Nall et al. (2015) and Ros et al. (2013) studies. However, this latter factor is only going to be significant if the marina is popular among nonresident vessels, so that new propagules are brought in; and (f) Proximity to the Suez Canal. The Suez Canal factor is especially prominent in the Eastern Mediterranean for NIS of Indo-Pacific origin, some of which have then spread westwards (Occhipinti-Ambrogi \& Galil, 2010; Tzomos et al., 2010). Many of these taxa are new to the region, especially those illustrated in the NIS compositions of the Cretan 
and Cypriot marinas; the Suez Canal vector of course is specific to the Mediterranean basin and urgently warrants some sort of specific targeted management (Galil et al., 2017), as its risk level for facilitating further invasions is assumed to be very high.

The suite of factors found here to influence NIS assemblage similarities between marinas differ from those linked to total species richness, providing evidence to accept that environmental matching plays a dominant role in affecting NIS similarities across regions, as found in Simpson (2017). Here the stronger environmental factors were temperature, primary productivity, biogeographic region, climate type. Yet, proximity to the Suez Canal also exerts a strong influence in this context. The nMDS plot reveals an unusual grouping of highly similar NIS assemblages found in marinas (40\%) spanning from Spain to Sicily, which is explained in the LINKTREE owing to similar temperatures on sampling date above $25^{\circ} \mathrm{C}$ and similar primary productivity values.

Several abiotic factors are shown to significantly affect both these NIS richness and assemblages in the studied marinas, which may imply that on a local scale, total NIS richness is influenced by certain factors (such as proximity to other vectors), replaced by environmental factors (such as temperature, salinity and primary productivity) when internal NIS assemblages are compared across the entire Mediterranean region as environmental matching comes out to be more dominant. However, temperature and proximity to the Suez Canal are factors commonly shared as important by both tests. Average sea surface water temperature on sampling date is important for explaining which minimum temperatures must be reached to influence higher total NIS, as most species need a minimum temperature to be triggered before they can spawn (Minchin \& Gollasch, 2003), and a study from both US coasts by Lord, Calini \& Whitlatch (2015) also found minimum temperature to be a key factor correlating to similar NIS assemblages between sites, further supporting these findings.

High similarities in NIS assemblages between marinas in Finike (Turkey) and Agios Nikolaos (Crete, Greece) were expected to be found here in their marinas, as dozens of live-aboard vessels collectively relocated from Finike, Turkey to winter in Greece in late 2014 due to political instability in Turkey (AU, personal communications with many boaters), but similarity was not as high as expected. However, some NIS found in Turkey, i.e. C. brunnea and Paradella dianae (Menzies, 1962), are from boat-hulls which had just travelled to Greece, but which had not yet established in the Turkish marinas (Ulman et al., 2017), but may do so in time. 
There are a few outlying marinas in relation to their distinctive NIS assemblages owing to a combination of selected abiotic factors. The two Istanbul marinas are in a very distinct sector of the Mediterranean (the Bosphorus Strait), with much lower salinities of about 25 PPT. Ataköy, Istanbul host some well-known local NIS such as the sea snail Rapana venosa (Valenciennes, 1846); whereas Kalamiş (Istanbul) and Marina Terre Rosse in Piombino, Tuscany, Italy (another marina outlier), are both dominated by the euryhaline serpulid $F$. enigmaticus, likely influenced by these lower salinity levels, Ficopomatus enigmaticus is a well-known estuarine and transitional water ecosystem engineer in creating additional hard substrate, thus accelerating the success for other NIS and has been linked to triggering 'invasional meltdown' of local communities (Simberloff \& Von Holle, 1999; Heiman \& Micheli, 2010). Marina Terre Rosse is a unique marina located a little upstream from the sea inside a saltwater canal with limited water exchange, likely resulting in anoxic conditions. Other outliers include Sorrento (Italy), which is the only completely open marina, and Finike with its salinity of 20 PPT, about half the Mediterranean average, due to a river positioned less than a kilometre from its entrance. Fethiye (Turkey) is another outlier as it has many sizeable fish farms in its bay, which may have directly contributed to its unique NIS assemblage by providing exceptionally high nutrient enrichment and/or by provisioning associated species. The marina in Rhodes (Greece) shows much affinity to the other Greek marinas despite being only 25 n.m. in distance from Netsel Marmaris Marina (Turkey), which it showed no affinity with, a fact that suggests popular travel routes as opposed to proximity likely influence similar assemblages in this region.

These results certainly point to the magnitude of the biofouling vector in the spread of NIS in the Mediterranean, as many of these marinas are isolated habitats, yet many are shown here to be connected to other marinas via their fouling communities despite great distances, where boat travel is the most plausible explanation for the spreading of most of the species found here. In fact, natural dispersal is not an option for sessile or semi-sessile species with short larval stages or no larvae, as most of the NIS in these assemblages. Although there are some NIS such as the decapod Dyspanopeus sayi (Smith, 1869) for which larval dispersal cannot be ruled out (Marco-Herrero et al., 2013). Examples of common species found on boat-hulls include $A$. verticillata, C. scaura, , $H$. dirampha, H. elegans, P. magna and S. plicata (see Ulman et al., 2017).

A study testing several of the same marina factors as this study (Foster et al., 2016) for NIS presences in UK marinas, found freshwater input, marina opening width and total seawall length to be significant factors. However, none of those factors were significant here, where the role of climate and proximity to the Suez Canal were overwhelming and may have masked these weaker factors. 
This indicates that different regions likely have different major contributing factors, thus management may need to be specially tailored for different subregions.

This study demonstrates that as many as 27 NIS coexist in a single marina, which is the second highest number of macrozoobenthic NIS ever recorded in a marina, in the Old Venetian Harbour, Crete, and the highest found thus far in the Mediterranean. This marina is in rather close proximity to the Suez Canal comparatively to the other marinas $(<850 \mathrm{~km})$ and is also located next to a large shipping port, which was shown here as a major contributing vector for enriching higher total NIS numbers. This work demonstrates how recreational marinas are certainly hot-spots for NIS in the Mediterranean, and with a certain level of incoming and outgoing traffic, these can be important hubs for the transfer of NIS to other localities. Outside the Mediterranean, marinas with highest NIS richness were found in Marina Del Rey, California, USA with 29 recorded NIS (California Department of Fish and Game, 2008), the NE United States with 18 species (Pederson et al., 2005), 18 from west Scotland (Nall et al., 2015), 16 from Madeira, Portugal (however, these were found cumulatively over a 6 year period; Canning-Clode et al., 2013); and 13 from England (Bishop et al., 2015a; Foster et al., 2016), although these totals are not directly comparable, due to the variability in both sampling strategies and targeted taxa. Future sampling should consider standardizing both the sampling techniques and the targeted species so data can be comparable across borders.

Many of these NIS are widespread across the Mediterranean (Tab. 2), some of which have been known for decades, i.e., $A$. verticillata and $H$. elegans, and some of which have only recently appeared, i.e, Watersipora arcuata Banta, 1969 and Stenothoe georgiana Bynum \& Fox, 1977 (Fernandez-Gonzalez \& Sanchez-Jerez, 2017; Ferrario et al., 2017). However, special attention should also be paid to rare NIS only found here in just one or a few localities, such as the ascidians Phallusia nigra Savigny, 1816 and Polyandrocarpa zorritensis (Van Name, 1931), the molluscs Chama asperella Lamarck, 1819 and Malleus regula (Forsskål in Niebuhr, 1775), the sea spider Achelia sawayai Marcus, 1940, the isopod Cymodoce fuscina Schotte \& Kensley, 2005, the amphipod A. longimerus and the crab Charybdis (Gonioinfradens) paucidentatus [A. Milne-Edwards, 1861] (Ulman et al., 2017).

While there are many NIS recorded in marinas, it is not yet understood how these hot-spots affect the natural biodiversity on a broader-scale (i.e., outside the marinas). For example, most of these species seem to be restricted to the artificial habitats of the marinas themselves due to both limited circulation and/or larval dispersal regimes, and because the surrounding habitats are unsuitable to 
host fouling species. However, some NIS have proven capable of colonizing numerous marinas across the Mediterranean Sea (up to $74 \%$ of marinas), even though many of the marinas have distinct underlying abiotic factors, which shows the potential for some NIS to adapt to a wide-range of conditions, thus eventual establishment success to neighbouring natural habitats cannot be ruled out.

There is currently a huge gap in knowledge on biological traits (i.e., dispersal characteristics, space requirements, competition; Cardeccia et al., 2018) and biotic resistance (i.e., pathogens, parasites, competitors and native predators of NIS species) that has to be better understood before these factors can also be incorporated into bioinvasions modelling to make it more integrative and robust (Cardeccia et al., 2018; Lockwood et al., 2009; Simberloff \& Von Holle 1999). These biological interactions largely affect NIS population sizes and obviously ecosystem dynamics, but as this is a fairly new and emerging field of research, it requires targeted collaboration amongst scientists, which has already been initiated by some local initiatives, such as the LifeWatchGreece Research Infrastructure Project (see polytraits.lifewatchgreece.eu). It should also be considered that other abiotic factors not investigated here may also play a role in shaping NIS patterns and distributions in Mediterranean marinas; for example, we also hypothesise that pollution levels and dissolved oxygen would be interesting to test in subsequent studies, as high pollution levels cause a reduction in biodiversity, unless the species is adapted or tolerant to those conditions, as those sites favour opportunistic NIS (Bellou et al., 2016).

The completion of this baseline study largely facilitates the ongoing monitoring of Mediterranean marinas for both new NIS and their spreading because of the patterns it provides for further comparisons with additional data in the future. Future studies will inevitably focus on quantitative small-scale changes over time, that is the dynamics of the NIS assemblages within marinas, and thus they will make it possible for more powerful models to be successfully applied.

The Mediterranean emerges as a unique large-scale experimental facility in being the most popular destination both for recreational boaters and for NIS, and purpose fit solutions are urgently needed to buffer from additional swarms of invaders, as has already been initiated for aquaculture and ballast water. The next step for biofouling in the Mediterranean is to provide some effective preventive regulations, as other countries have commenced (e.g., Australian Marine Conservation Society, 2015; Ministry for Primary Industries, 2017). In fact, a new international project is currently in the planning process to address biofouling management titled the "Glofouling project", a collaboration between the Global Environment Facility (GEF), the United Nations Development 
Programme (UNDP) and the International Maritime Organization (IMO). It is hopeful this large endeavour will have regionally sculpted management variations to address the underlying factors generating NIS hotspots and hubs.

As the Mediterranean is an enclosed sea, basin-wide management preventing entry of new invaders to the basin in theory should be relatively controllable, but would require imposed regulations on long-distance travelling boats, resulting from cooperation amongst the countries bordering the Strait of Gibraltar, the Suez Canal and the Bosphorus Strait; although such a collaboration is highly unlikely at present (Galil et al., 2015).

\section{Acknowledgements}

This work was funded by a PhD Scholarship awarded to Aylin Ulman from the MARES- Erasmus Mundus Joint Doctoral Fellowship Program in Marine Ecosystem Health and Conservation. MARES is a Joint Doctorate programme selected under Erasmus Mundus coordinated by Ghent University (FPA 2011-0016). A COST Action \#1209 grant was provided to Aylin Ulman to visit the University of Alicante, Spain. 


\section{References}

Airoldi, L., Turon, X., Perkol-Finkel, S., Rius, M., 2015. Corridors for aliens but not for natives: effects of marine urban sprawl at a regional scale. Divers. Distrib. 21, 755-768.

Ashton, G., Boos, K., Shucksmith, R., Cook, E., 2006. Rapid assessment of the distribution of marine non-native species in marinas in Scotland. Aq. Inv. 1, 209-213.

Ashton, G., Davidson, I., Ruiz, G., 2014. Transient small boats as a long-distance coastal vector for dispersal of biofouling organisms. Estuaries Coasts 37, 1572-1581.

Australian Marine Conservation Society, 2015. Review of National Marine Pest Biosecurity: A response. Invasive Species Council.

Bax, N., Williamson, A., Aguero, M., Gonzalez, E., Geeves, W., 2003. Marine invasive alien species: a threat to global biodiversity. Mar. Policy 27, 313-323.

Bellou, N., Canning-Clode, J., Tsiamis, K., Pancucci, A., 2016. Diversity of fouling species grown on artificial substrata deployed in a polluted and an unpolluted site in the Aegean Sea. In: 9th Symposium on Oceanography \& Fisheries Proceedings. Patras, Greece.

Bianchi, C. N., Morri, C., 2000. Marine biodiversity of the Mediterranean Sea: Situation, problems and prospects for future research. Mar. Pollut. Bull. 40, 367-376.

Bishop, J., Wood, C., Lévêque, L., Yunnie, A., Viard, F. 2015a. Repeated rapid assessment surveys reveal contrasting trends in occupancy of marinas by non-indigenous species on opposite sides of the western English Channel. Mar. Pollut. Bull. 95(2), 699-706.

Bishop, J., Wood, C., Yunnie, A., Griffiths, C., 2015b. Unheralded arrivals: non-native sessile invertebrates in marinas on the English coast. Aquat. Invasions 10, 249-264.

Boudouresque, C.F., Klein, J., Ruitton, S., Verlaque, M., 2010. Biological invasion: the Thau Lagoon, a Japanese biological island in the Mediterranean Sea, in Global change: mankind-marine environment interactions (pp. 151-156). Springer, Dordrecht.

Bray, J.R., Curtis, J.T., 1957. An ordination of the upland forest communities of southern Wisconsin. Ecol. Monogr. 27, 325-349.

Brock-Morgan, A., 2010. The effect marina design and recreational boating has on the spread of nonindigenous species. Plymouth St. Sci. 3, 163-206.

California Department of Fish and Game, 2008. Introduced aquatic species in the marine and estuarıne waters of California. California State Legislature, 73.

Callier, M., Fletcher, R., Thorp, C., Fichet, D., 2009. Macrofaunal community responses to marinarelated pollution on the south coast of England and west coast of France. J. Mar. Biol. Assoc. U. K. 89, 19-29.

Canning-Clode, J., Fofonoff, P., McCann, L., Carlton, J.T., Ruiz, G., 2013. Marine invasions on a subtropical island: fouling studies and new records in a recent marina on Madeira Island (Eastern Atlantic Ocean). Aquat. Invasions 8, 261-270.

Cappato, A., Canevello, S., Baggiani, B., 2011. Cruises and Recreational Boating in the Mediterranean. IIC: Istituto Internazionale delle Comunicazioni, Genoa - Italy. Plan Bleu., Sophia Antipolis: UNEP/MAP Regional Activity Centre.

Cardeccia, A., Marchini, A., Occhipinti-Ambrogi, A., Galil, B. S., Gollasch, S., Minchin, D., Narscius, A., Olenin, S., Ojaveer, H., 2018. Assessing biological invasions in European Seas: biological traits of the most widespread non-indigenous species. Estuar. Coast Shelf Sci. 201,17-28.

Carlton, J.T., 2003. Invasive species: Vectors and management strategies. Island Press, Washington DC.

Casas-Monroy, O., Roy, S., Rochon, A, 2011. Ballast sediment-mediated transport of non-indigenous species of dinoflagellates on the East Coast of Canada. Aquat. Invasions 6, 231-248.

Chapman, J., Carlton, J.T., 1991. A test of criteria for introduced species: the global invasion by the isopod Synidotea laevidorsalis (Miers, 1881). J. Crustacean Biol. 11, 386-400.

Clark, G.F., Johnston, E., 2005. Manipulating larval supply in the field: a controlled study of marine invasibility. Mar. Ecol. Prog. Ser. 298, 9-19. 
Clarke, K.R., 1993. Non-parametric multivariate analyses of changes in community structure. Aus. J. Ecol. 18, 117-143.

Clarke, K.R., Gorley, R.N., 2006. PRIMER v6: User manual/Tutorial. PRIMER-E. Plymouth, UK.

Clarke, K.R., Warwick, R.M., 2001. Change in marine communities: an approach to statistical analysis and interpretation. PRIMER-E. Plymouth, UK.

Clark, G.F., Johnston, E.L., 2009. Propagule pressure and disturbance interact to overcome biotic resistance of marine invertebrate communities. Oikos 118, 1679-1686.

Clarke-Murray, C., Pakhamov, E.A., Therriault, T.W., 2011. Recreational boating: a large unregulated vector transporting marine invasive species. Divers. Distrib. 17, 1161-1172.

Clarke-Murray, C., Gartner, H., Gregr, E.J., Chan, K., Pakhomov, E., Therriault, T.W., 2014. Spatial distribution of marine invasive species: environmental, demographic and vector drivers. Divers. Distrib 20, 824-836.

Cognetti, G., Maltagliati, F., 2000. Biodiversity and adaptive mechanisms in brackish water fauna. Mar. Pollut. Bull. 40, 1-17.

Cohen, A.N., Harris, L.H., Bingham, B.L., Carlton, J.T., Chapman, J., Lambert, C.C., Schwint, E., 2005. Rapid assessment survey for exotic organisms in southern California bays and harbours, and abundance in port and non-port areas. Biol. Invasions 7, 995-1002.

Colautti, R., Grigorovich, I., Maclsaac, H.J., 2006. Propagule pressure: a null model for biological invasions. Biol. Invasions 8: 1023-1037.

Colella, S., Falcini, F., Rinaldi, E., Sammartino, M., Santoleri , R., 2016. Mediterranean Ocean Colour Chlorophyll Trends. PLoS ONE 11, e0155756.

Connell, S.D. 2000. Floating pontoons create novel habitats for subtidal epibiota. J. Exp. Mar. Biol. Ecol. 247, 183-194.

Connell, S.D., 2001. Urban structures as marine habitats: an experimental comparison of the composition and abundance of subtidal epibiota among pilings, pontoons and rocky reefs. Mar. Environ. Res. 52, 115-125.

Connell, S.D., Glasby. T.M., 1999. Do urban structures influence local abundance and diversity of subtidal epibiota? A case study from Sydney Harbour, Australia. Mar. Environ. Res. 47, 373387.

Dafforn, K., Johnston, E., Glasby, T., 2009. Shallow moving structures promote marine invader dominance. Biofouling: J. Bioadhesion Biofilm Res. 25, 277-287.

De'ath, G., 2002. Multivariate regression trees: a new technique for modeling species-environment relationships. Ecology 83, 1105-1117.

Early, R., Sax, D., 2014. Climatic niche shifts between species' native and naturalized ranges raise concern for ecological forecasts during invasions and climate change. Glob. Ecol. Biog. 23, $1356-1365$.

EUROPA, 2007. Developing an EU Framework for Invasive Alien Species. Discussion Paper European Commission. Brussels, Belgium.

European Commission, 2016. On the application of the Water Framework Directive (WFD) and the Marine Strategy Framework Directive (MSFD) in relation to aquaculture. Marine Strategy Framework Directive. Commission Staff Working Document. European Union, Brussels, Belgium.

European Environment Agency, 2012. The impacts of invasive alien species in Europe. Technical Report 16. Publications Office of the European Union, Luxembourg.

Fernandez-Gonzalez, V., Sanchez-Jerez, P., 2017. Fouling assemblages associated with off-coast aquaculture facilities: an overall assessment of the Mediterranean Sea. Mediterr. Mar. Sci. 18, 87-96.

Ferrario, J., Caronni, S., Occhipinti-Ambrogi, A., Marchini, A., 2017. Role of commercial harbours and recreational marinas in the spread of non-indigenous fouling species. Biofouling 33, 651-660.

Floerl, O., Inglis, G., 2003. Boat harbour design can exacerbate fouling. Aust. Ecol. 28, 116-127. 
Foster, V., Giesler, R., Wilson, A., Nall, C., Cook, E., 2016. Identifying the physical features of marina infrastructure associated with the presence of non-native species in the UK. Mar. Biol. 163.

Galil, B.S., Boero, F., Campbell, M.L., Carlton, J.T., Cook, E., Fraschetti, S., Golasch, S., Hewitt, C., Jelmert, A., MacPherson, E., Marchini, A., McKenzie, C., Minchin, D., Occhipinti-Ambrogi, A., Ruiz, G.M., 2015. 'Double trouble': the expansion of the Suez Canal and marine bioinvasions in the Mediterranean Sea. Biol. Inv. 17, 973-976.

Galil, B.S., Marchini, A., Occhipinti-Ambrogi, A., Ojaveer H., 2017. The enlargement of the Suez Canal-Erythraean introductions and management challenges. Mgmt. Biol. Inv. 8, 12.

Galil, B.S., Marchini, A., Occhipinti-Ambrogi, A., 2018. East is east and West is west? Management of marine bioinvasions in the Mediterranean Sea. Estuar. Coast. Shelf Sci. 201, 7-16.

Gallardo, B., Aldridge, D.C., 2013. The 'dirty dozen': socioeconomic factors amplify the invasion potential of twelve high risk aquatic invasive species in Great Britain and Ireland. J. Appl. Ecol. 50, 757-766.

Glasby, T., Connell, S., Holloway, M., Hewitt, C., 2007. Nonindigenous biota on artificial structures: could habitat creation facilitate biological invasions? Mar. Biol. 151, 887-895.

Google Earth Pro, 2016. Version 7.1.7.2602 (accessed 03/06/2017).

Guidetti, P., Baiata, P., Ballesteros, E., Di Franco, A., Hereu, B., Macpherson, E., Micheli, F., Pais, A., Panzalis, P., Rosenberg, A., Zabala, M., Sala, E., 2014. Large-Scale Assessment of Mediterranean Marine Protected Areas Effects on Fish Assemblages. PLoS One 9, e91841.

Heiman, K. \& Micheli, F., 2010. Non-native ecosystem engineer alters estuarine communities. Integr. Comp. Biol. 50, 226-236.

Hopkins, G.A., Forrest, B.M. 2008. Management options for vessel hull fouling: an overview of risks posed by in-water cleaning. ICES J. Mar. Sci. 65, 811-815.

Jackson, J., 2008. Ecological extinction and evolution in the brave new ocean. Proc. Natl. Acad. Sci. U S A. 105 (Supplement 1), 11458-11465.

Jiminez, H., Keppel, E., Chang, A.L., Ruiz, G.M., 2018. Invasions in Marine Communities: Contrasting species richness and community composition across habitats and salinity. Estuaries Coast 41 , 484-494.

Katsanevakis, S., Coll, M., Piroddi, C., Steenbeek, J., Ben Rais Lasram, F., Zenetos. A., Cardoso, A.C. 2014. Invading the Mediterranean Sea: biodiversity patterns shaped by human activities. Front. Mar. Sci. 1, 11.

Kendall, M.G., 1970. Rank correlation methods. London: Griffin.

Lehtiniemi, M., Ojaveer, H., David, M., Galil, B., Gollasch, S., McKenzie, C., Minchin, D., OcchipintiAmbrogi, A., Olenin, S., Pederson, J., 2015. Dose of truth-monitoring marine non-indigenous species to serve legislative requirements. Mar. Policy 54, 26-35.

Lockwood, J., Cassey, P. \& Blackburn, P., 2005. The role of propagule pressure in explaining species invasions. Trends Ecol. Evol. 20, 223-228.

Lockwood, J.L., Cassey, P., Blackburn, T.M. 2009. The more you introduce the more you get: the role of colonization pressure and propagule pressure in invasion ecology. Divers. Dist. 15, 904910.

Lord, J., Calini, J., Whitlatch, R., 2015. Influence of seawater temperature and shipping on the spread and establishment of marine fouling species. Mar. Biol. 162, 2481-2492.

Marchini, A., Ferrario, J., Minchin, D., 2015. Marinas may act as hubs for the spread of the pseudoindigenous bryozoan Amathia verticillata (Delle Chiaje, 1822) and its associates. Sci. Mar. 79, 355-365.

Marco-Herrero E., Guerao G., Cuesta J.A., 2013. Morphology of the larval stages of a Mediterranean population of the allochthonous Say's mud crab, Dyspanopeus sayi (Decapoda: Brachyura: Panopeidae). Sci. Mar. 77: 341-352

McCullagh, P., Nelder, J.A., 1983. Generalized Linear Models. 1st edition ed. London: Chapman \& Hall. 
Megina, C., González-Duarte, M.M., Lopez-Gonzalez, P.J., 2016. Benthic assemblages, biodiversity and invasiveness in marinas and commercial harbours: an investigation using a bioindicator group. Biofouling 32, 465-475.

Minchin, D., Gollasch, S., 2003. Fouling and ships hulls: how changing circumstances and spawning events may result in the spread of exotic species. Biofouling 19, 111-122.

Minchin, D., Floerl, O., Savini, D., Occhipinti-Ambrogi, A., 2006. Small craft and the spread of exotic species, in John D and Davenport JL (Eds.), The ecology of transportation: Managing mobility for the environment. Berlin: Springer, pp. 99-116.

Mineur, F., Cook, E.J., Minchin, D., Bohn, K., MacLeod, A., Maggs, C., 2012. Changing coasts: Marina aliens and artificial structures. Oceanography and Marine Biology: An annual review. France.

Ministry for Primary Industries, 2017. Guidance document for the craft risk management standard Biofouling on vessels arriving to New Zealand. Accompanying information for the Craft Risk Management Standard for Biofouling on vessels arriving to New Zealand. New Zealand Government: Manatu Ahu Matua, New Zealand.

Nall, C., Guerin, A., Cook, E., 2015. Rapid assessment of marine non-native species in northern Scotland and a synthesis of existing Scottish records. Aq. Inv.10, 107-121.

Naylor, R., Williams, S.L., Strong, D.R., 2001. Aquaculture-a gateway for exotic species. Science 294, 1655-1656.

Occhipinti-Ambrogi, A., 2007. Global change and marine communities: alien species and climate change. Mar. Pollut. Bull. 55, 342-352.

Occhipinti-Ambrogi, A., Galil, B.S., 2010. Marine alien species as an aspect of global change. Adv. Oceanogr. Limnol. 1, 199-218.

Ojaveer, H., Galil, B. S., Minchin, D., Olenin, S., Amorim, A., Canning-Clode, J., Chainho, P., Copp, G., Gollasch, S., Jelmert, A., Lehtiniemi, M., McKenzie, C., Mikuš, J., Miossec, L., OcchipintiAmbrogi, A., Pecarevic, M., Pederson, J., Quilez-Badia, G., Wijsman, J., Zenetos, A., 2014. Ten recommendations for advancing the assessment and management of non-indigenous species in marine ecosystems. Mar. Policy 44, 160-165.

Olenin, S., Minchin, D., Daunys, D., 2007. Assessment of biopollution in aquatic systems. Mar. Pollut. Bull. 55, 379-394.

Olenin, S., Narscius, A., Gollasch, S., Lehtiniemi, M., Marchini, A., Minchin, D., Srëbalienè, G., 2016. New arrivals: An indicator for Non-indigenous Species introductions at different geographical scales. Front. Mar. Sci. 3.

Pederson, J., Bullock, R., Carlton, J., Dijkstra, J., Dobrowski, N., Dyrynda, P., Fisher, R., Harris, L., Hobbs, L., Lambert, G., Lazo-Wesem, E., Matheson, A., Miglieta, M.P., Smith, J. Smith, J.,Tyrrell, M., 2005. Marine invaders in the northeast: rapid assessment survey of non-native and native marine species of floating dock communities. Report of the 3-9 August 2003 survey. Cambridge, Massachusetts: MIT Sea Grant College Program.

Peters, K., Sink, K., Robinson, T.B. 2017. Raising the flag on marine alien fouling species. Mgmt. Biol. Inv. 8, 1-11.

Peel, M. C., Finlayson, B.L., McMahon, T.A., 2007. Updated world map of the Koppen-Geiger climate classification. Hydrol. Earth Syst. Sci. 11, 439-473.

Popescu, I., 2010. Fisheries in Sicily. Policy Department B: Structural and Cohesion Policies. Brussels, Belgium, European Parliament.

R Core Team, 2016. R: A language and environment for statistical computing. R Foundation for Statistical Computing. Vienna, Austria.

Ros, M., Guerra-García, J. M., González-Macías, M., Saavard A., Lopez-Fe, C., 2013. Influence of fouling communities on the establishment success of alien caprellids (Crustacea: Amphipoda) in Southern Spain. Mar. Biol. Res. 9, 293-305.

Ruesink, J., Lenihan, H., Trimble, A., Heiman K., Micheli, F., Byers, J., Kay, M., 2005. Introduction of non-native oysters: ecosystem effects and restoration implications. Annu. Rev. Ecol. Evol. Syst. 36, 643-689. 
Seebens, H., Schwartz, N., Schupp, P.J., Blasius, B., 2016. Predicting the spread of marine species introduced by global shipping. Proc. Natl. Acad. Sci. U. S. A 113, 5646-5651.

Simberloff, D., Von Holle, B., 1999. Positive interactions of nonindigenous species: invasional meltdown? Biol. Invasions 1, 21-32.

Simkanin, C., Davidson, I. C., Therriault, T.W., Jamieson G., Dower, F., 2017. Manipulating propagule pressure to test the invasibility of subtidal marine habitats. Biol. Invasions 19, 1565-1575.

Simpson, T., Smale, D., McDonald, J., Wernberg, T., 2017. Large scale variability in the structure of sessile invertebrate assemblages in artificial habitats reveals the importance of local-scale processes. J. Exp. Mar. Biol. Ecol. 494, 10-19.

Trujillo, P., Piroddi, C., Jacquet, J., 2012. Fish farms at sea: the ground truth from Google Earth. PLoS ONE 10, e0134745.

Tyberghein, L. , Verbruggen, H. , Pauly, K. , Troupin, C. , Mineur, F., De Clerck, O., 2012. Bio-ORACLE: a global environmental dataset for marine species distribution modelling. Global Ecol. Biogeog. 21, 272-281.

Tyrell, M., Byers, J., 2007. Do artificial substrates favor nonindigenous fouling species over native species? J. Exp. Mar. Biol. Ecol. 342, 54-60.

Tzomos, T., Chartosia, N., Christodoulou, M., Kitsos, M., 2010. New records and range expansion of lessepsian migrants in the Levantine and Aegean Seas. Mar. Biodivers. Rec. 3, e10.

Ulman, A., Ferrario, J., Occhipinti-Ambrogi, A., Arvanitidis, C., Bandi, A., Bertolino, M, Bogi, C., Chatzigeorgiou, G., Cicek, B.A., Deidun A., Ramos-Espla', A., Kocak, C., Lorenti, M., MartinezLaiz, G., Merlo, G., Princisgh, E., Scribano, G., Marchini, A., 2017. A massive update of nonindigenous species records in Mediterranean marinas. PeerJ 5, e3954.

Verling, E., Ruiz, G., Smith, L., Galil, B. S., Miller, A., Murphy K., 2005. Supply-side invasion ecology: characterizing propagule pressure in coastal ecosystems. Proc. R Soc. B Lond. (Biol) 272, $1249-1257$.

Wonham, M., Byers, J., Grosholz, E., Leung, B., 2013. Modeling the relationship between propagule pressure and invasion risk to inform policy and management. Ecol. Appl. 23, 1691-1706.

Worm, B., Barbier, E.B., Beaumont, N., Duffy, J.E., Folke, C., Halpern, B.S., Jackson, J., Lotze, H., Micheli, F., Palumbi, S., Sala, E., Selkoe E., Stachowicz, J., Watson, R., 2006. Impacts of biodiversity loss on ocean ecosystem services. Science 314, 787-790.

Zabin, C.J., Ashton, G.V., Brown, C.W., Davidson, I., Sytsma, M., Ruiz, G., 2014. Small boats provide connectivity for nonindigenous marine species between a highly invaded international port and nearby coastal harbors. Manag. Biol. Invasions 5, 97-112.

Zuur, A., leno, E., Elphick, C., 2010. A protocol for data exploration to avoid common statistical problems. Methods Ecol. Evol. 1, 3-14.

Zuur, A., Hilbe, J., leno, E. 2013. Beginner's Guide to GLM and GLMM with R: A Frequentist and Bayesian Perspective for Ecologists. Newburgh Highland Statistics Limited, U. K. 
Table 1 Number of NIS per marina (marina numbers from Table S1).

\begin{tabular}{|c|c|c|c|}
\hline Locality & \# NIS & Locality & \# NIS \\
\hline 1. Alicante & 10 & 26. Sorrento & 8 \\
\hline 2. Barcelona & 11 & 27. Villa Igiea, Palermo & 20 \\
\hline 3. Cap d'Agde & 8 & 28. La Cala, Palermo & 16 \\
\hline 4. La Grande-Motte & 7 & 29. Riposto & 13 \\
\hline 5. Port Camargue & 17 & 30. Siracusa & 16 \\
\hline 6. Saint Tropez & 4 & 31. Marzamemi & 11 \\
\hline 7. Cogolin & 6 & 32. Ragusa & 14 \\
\hline 8. Saint Maxime & 3 & 33. Licata & 11 \\
\hline 9. Cannes & 5 & 34. Msida & 14 \\
\hline 10. Antibes & 5 & 35. Valletta & 13 \\
\hline 11. Villefranche & 2 & 36. Chioggia & 9 \\
\hline 12. Alassio & 2 & 37. Venezia & 8 \\
\hline 13. Genoa & 5 & 38. Treporti & 7 \\
\hline 14. S. Margherita & 7 & 39. Heraklion & 27 \\
\hline 15. La Spezia & 7 & 40. Agios Nikolaos & 12 \\
\hline 16. Lerici & 10 & 41. Rhodes & 16 \\
\hline 17. Viareggio & 10 & 42. Ataköy, Istanbul & 4 \\
\hline 18. Piombino & 3 & 43. Kalamış, Istanbul & 4 \\
\hline 19. Scarlino & 7 & 44. Bodrum & 12 \\
\hline 20. Punta Ala & 2 & 45. Datça & 9 \\
\hline 21. Porto Torres & 10 & 46. Marmaris & 6 \\
\hline 22. Castelsardo & 8 & 47. Fethiye & 10 \\
\hline 23. Porto Rotondo & 3 & 48. Finike & 14 \\
\hline 24. Ostia, Rome & 9 & 49. Karpaz & 16 \\
\hline 25. Ischia & 5 & 50. Famagusta & 17 \\
\hline
\end{tabular}


Table 2 The most widespread NIS found in marinas (\% of marina distribution).

\begin{tabular}{lr|lr}
\hline Species & $\%$ & Species & $\%$ \\
\hline Styela plicata & 74 & Branchiomma bairdi & 30 \\
\hline Hydroides elegans & 66 & Paraleucilla magna & 24 \\
\hline Amathia verticillata & 62 & Ascidiella aspersa & 22 \\
\hline Caprella scaura & 58 & Arcuatula senhousia & 22 \\
\hline Celleporaria brunnea & 52 & Watersipora arcuata & 18 \\
\hline Paranthura japonica & 52 & Ciona robusta & 16 \\
\hline Brachidontes pharaonis & 34 & Tricellaria inopinata & 16 \\
\hline Hydroides dirampha & 32 & Stenothoe georgiana & 16 \\
\hline Mesanthura cf. romulea & 30 & Dendostrea. folium & 16 \\
\hline Paracerceis sculpta & 30 & Magallana gigas & 16 \\
\hline
\end{tabular}


Table 3 Coefficients from the Generalized Linear Model fitted to total number of NIS, using a log link function and a Poisson distribution. In categorical explanatory variables, estimates express the difference between each level of factors and the first level (which are considered in the intercept).

\begin{tabular}{lrr}
\hline Coefficient & Estimate & Standard Error \\
\hline Intercept* & 303.155 & 0.82703 \\
Temperature & 0.0279 & 0.01788 \\
Number of berths & 0.00026 & 0.00007 \\
Distance from the Suez Canal & -0.00093 & 0.00023 \\
Proximity to aquaculture & -0.23349 & 0.14285 \\
Proximity to commercial harbours & 0.44002 & 0.11872 \\
Presence of pontoons & -0.28360 & 0.17784 \\
Biogeographic sector C & 0.10509 & 0.43995 \\
Biogeographic sector D & 0.26092 & 0.48941 \\
Biogeographic sector E & 0.52156 & 0.57285 \\
Biogeographic sector I & -0.81707 & 0.56081 \\
Biogeographic sector K & -1.18805 & 0.59735 \\
Climate type Bsk & 1.12741 & 0.45492 \\
Climate type Csa & 0.31884 & 0.21890 \\
\hline Climate type Csb & 0.50441 & 0.32647 \\
\hline Represents values regarding marina & &
\end{tabular}

* Represents values regarding a marina with no vicinity to aquaculture sites and commercial harbours, and with no presence of pontoons, set in biogeographic sector B and climate type Bsh. 


\section{Figure captions:}

- Figure 1 Map of the Mediterranean Sea showing marina localities sampled for this study, with their corresponding assigned number from S1.

- Figure 2 Flow chart of statistical analyses applied to both the univariate and multivariate analyses testing presence-absence of non-indigenous species (NIS) against abiotic factors.

- Figure 3 Non-indigenous species (NIS) records shown proportionately for each marina sampled in the Mediterranean, by major taxon.

- Figure 4a Scatter plots showing the relationship between the total non-indigenous species (NIS) richness and each abiotic quantitative factor: (a) Temperature; (b) Number of berths; (c) Distance to Suez Canal; (d) Salinity; (e) Primary productivity; (f) Marina area; (g) Marina opening length. To aid visual interpretation, a LOESS smoothing curve was added. Abiotic factors are ordered according to the strength of their relationship, with significant factors presented first in bold text.

- Figure 4b Boxplots representing the relationships between total non-indigenous species (NIS) richness in marinas and each categorical qualitative abiotic factor; (a) Proximity to aquaculture sites; (b) Proximity to commercial harbours; (c) Presence of floating pontoons; (d) Biogeographic sectors; (e) Climate type; (f) Proximity to freshwater source; and (g) Presence of shipyard, significant factors in bold text. Red dots represent the mean, the black horizontal line in plots denotes the median of the data, and the black dots represent outliers.

- Figure 5 Two-dimensional nMDS plot of non-indigenous species (NIS) similarities for sampled Mediterranean marinas with marina numbers from S1. SIMPROF test results were superimposed, identified with different symbols for the 9 groups (a-i) of marinas with significantly $(\mathrm{P}<0.05)$ different NIS multivariate structure. Cluster results were also superimposed, groupings shown for similarity levels of $20 \%$ and $40 \%$.

- Figure 6 LINKTREE analysis results showing factors most responsible for separating marinas into groupings, according to their non-indigenous species (NIS) assemblage compositions with the strongest differences between marina groups having a higher B\% (absolute measure of group differences) from contributing factors (or pairs of factors if collinear). The plot displays only those divisions for which the SIMPROF test was significant $(p<0.05)$. For each split the ANOSIM test statistic ( $R=$ Rank similarity index) for each marina grouping is shown. 
Fig. 1

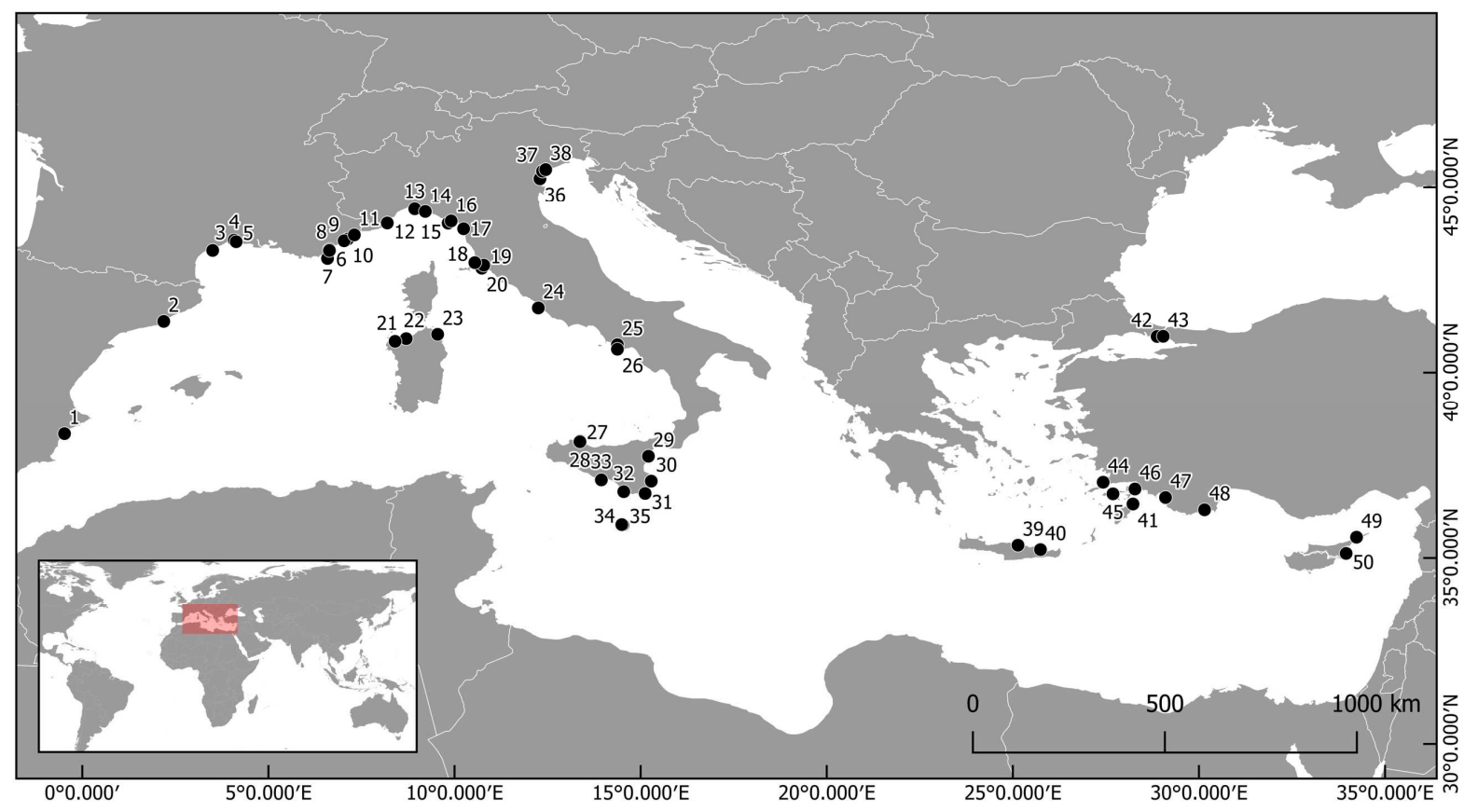


Fig. 2

Find best mode


Fig. 3

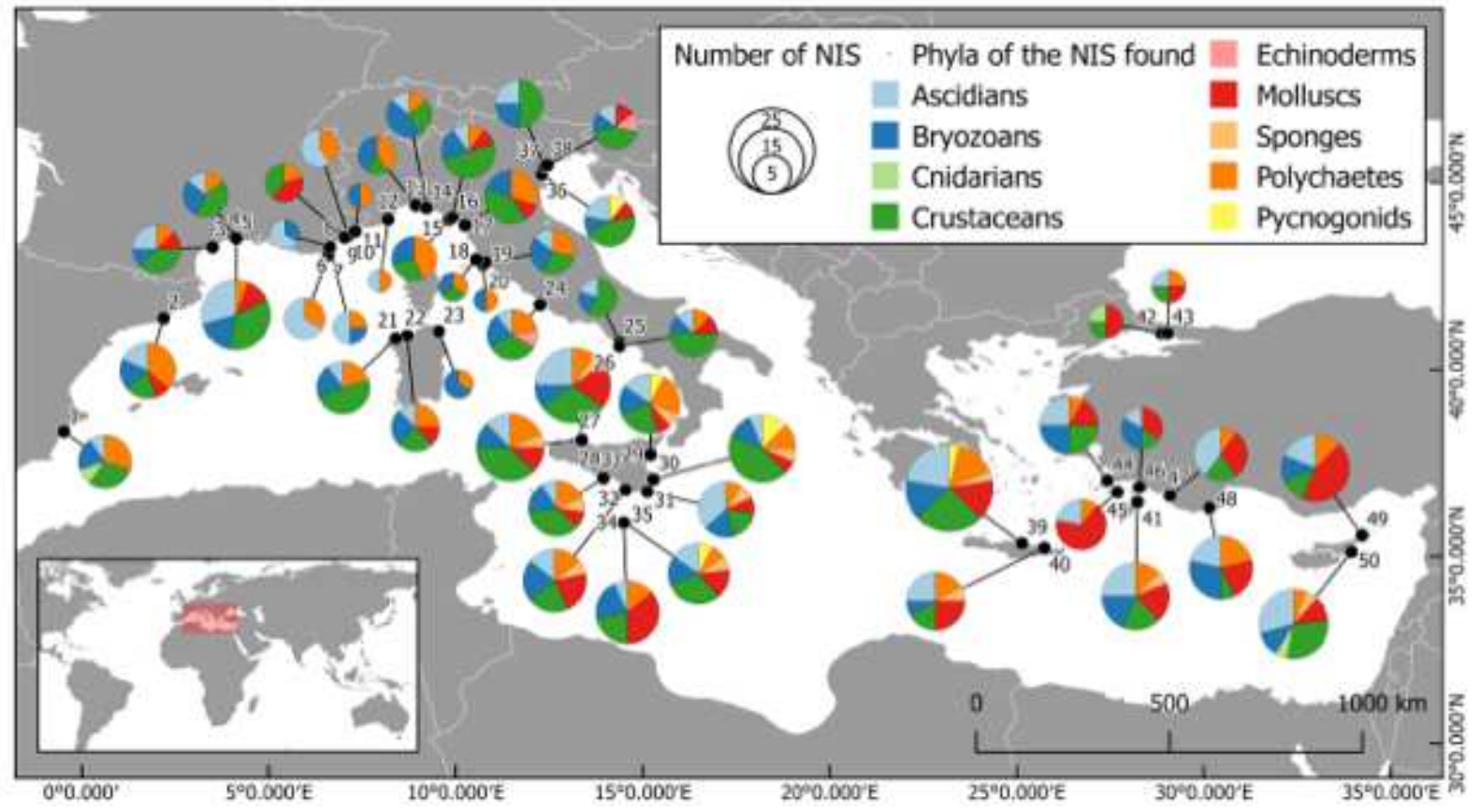


Fig. 4a
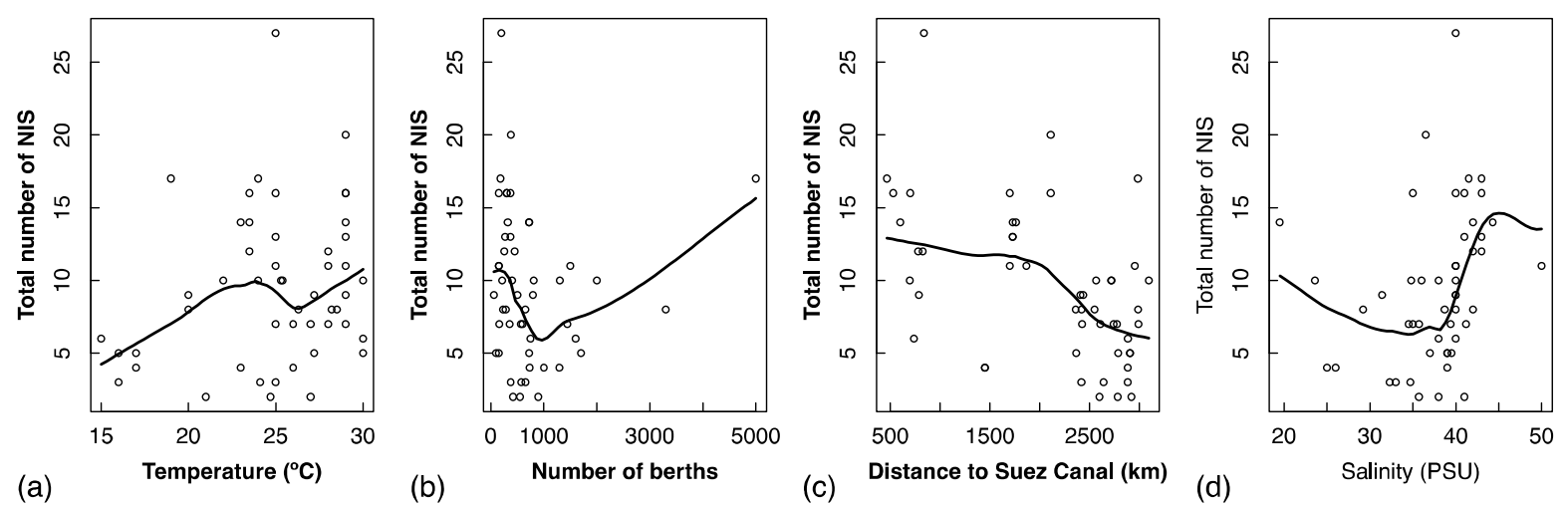

(a)

(b)

(c)
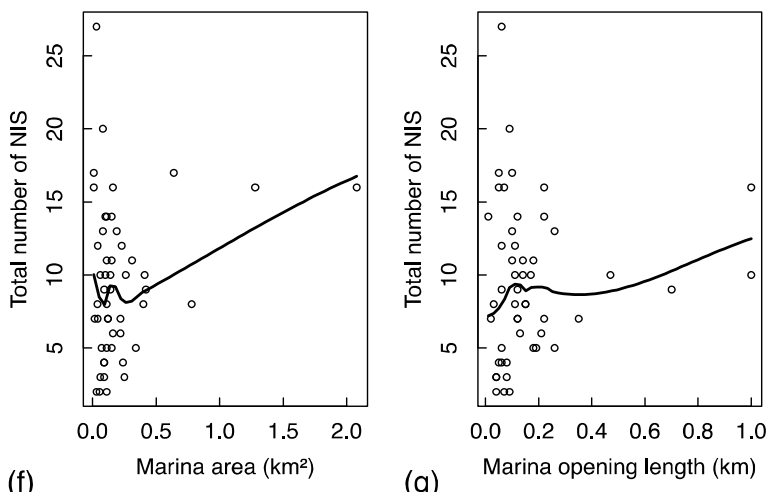

(e) Primary productivity $\left(\mathrm{g} \mathrm{C}^{3} \mathrm{~m}^{3}\right.$

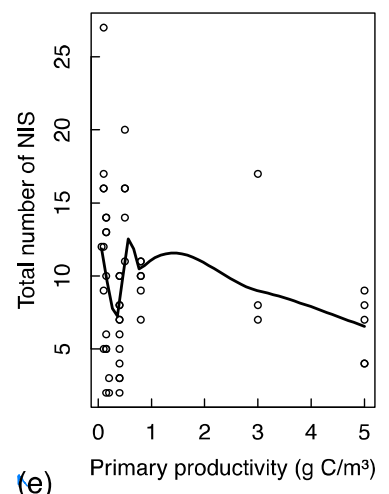

(f)

(g)

(d) 
Fig. 4b

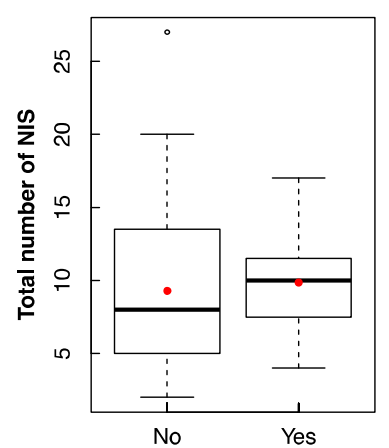

(a) Proximity to aquaculture sites

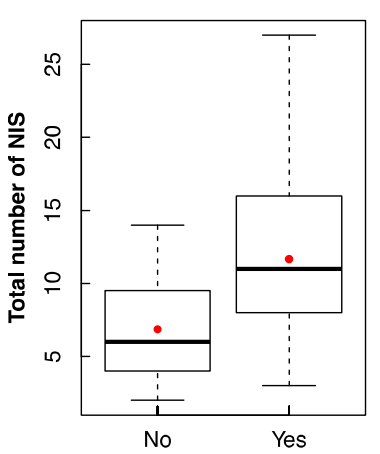

(b)

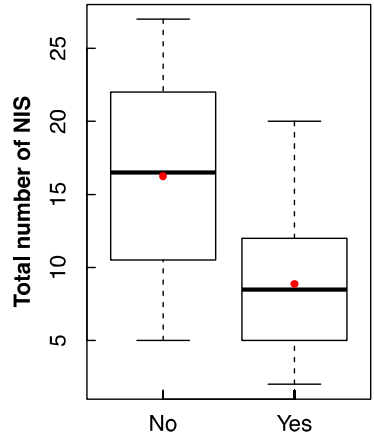

(c)

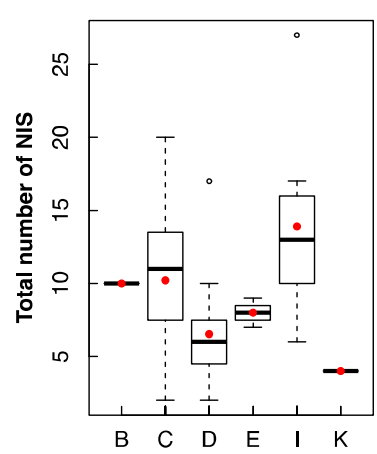

(d)

Biogeographic sectors

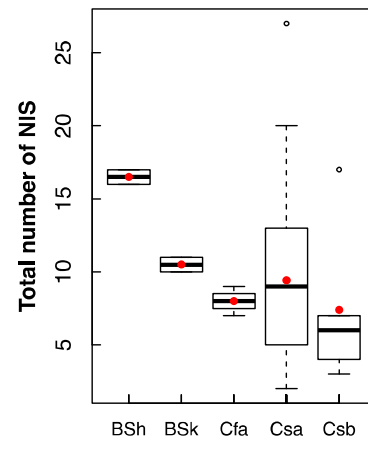

(e)

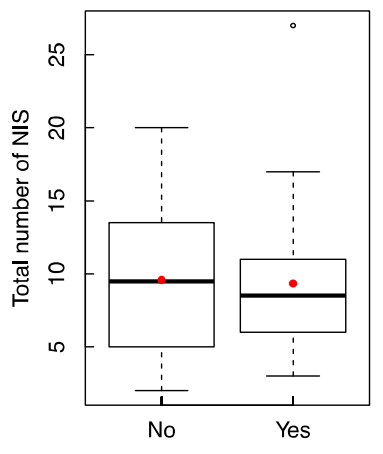

(f)

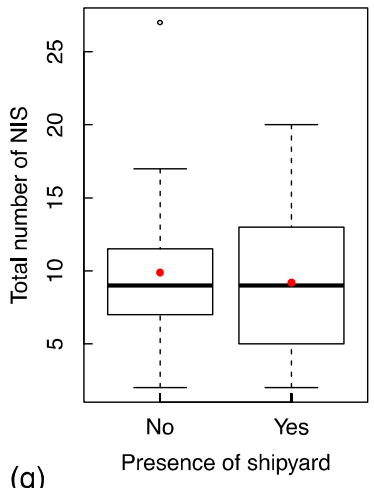


Fig. 5

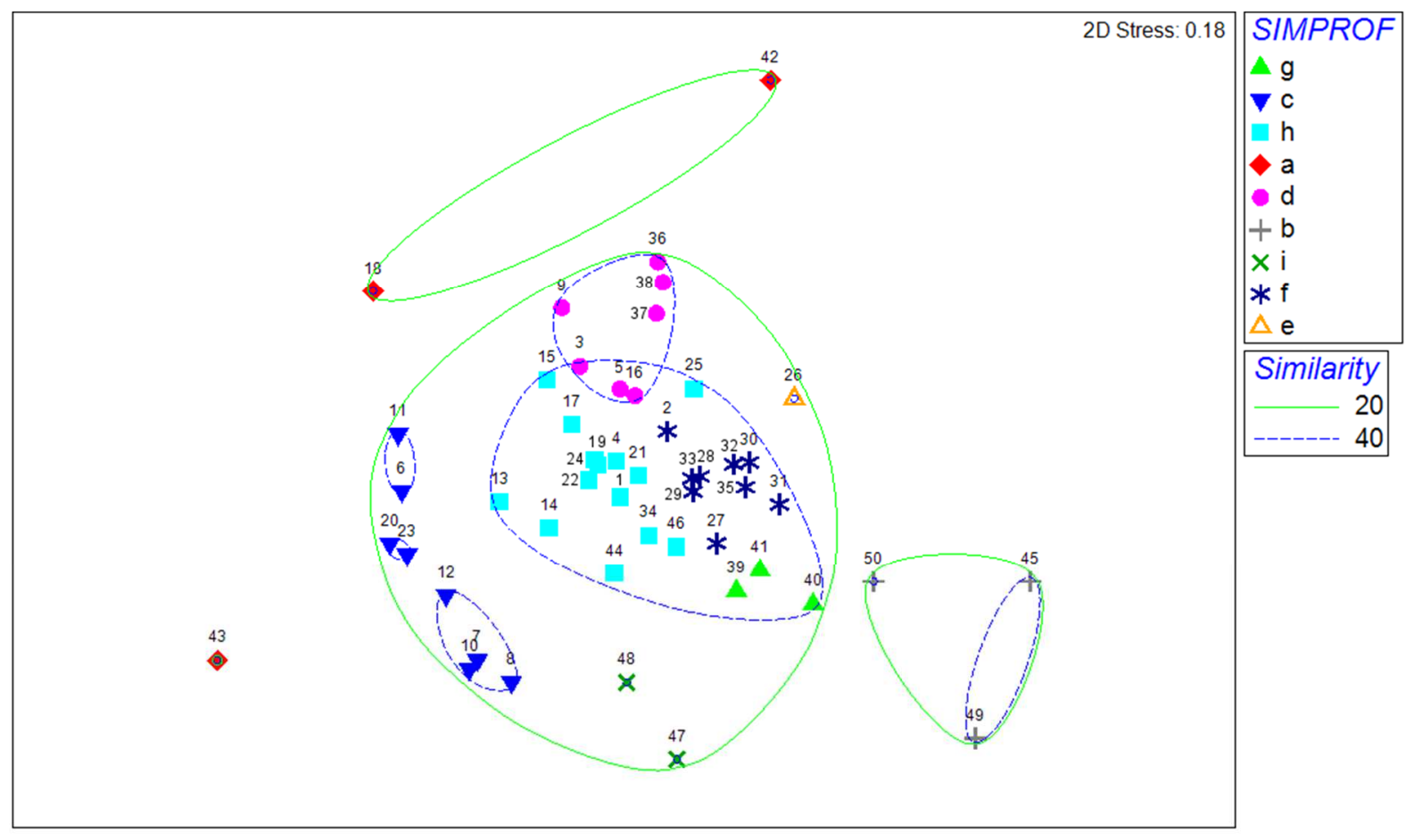


Fig. 6

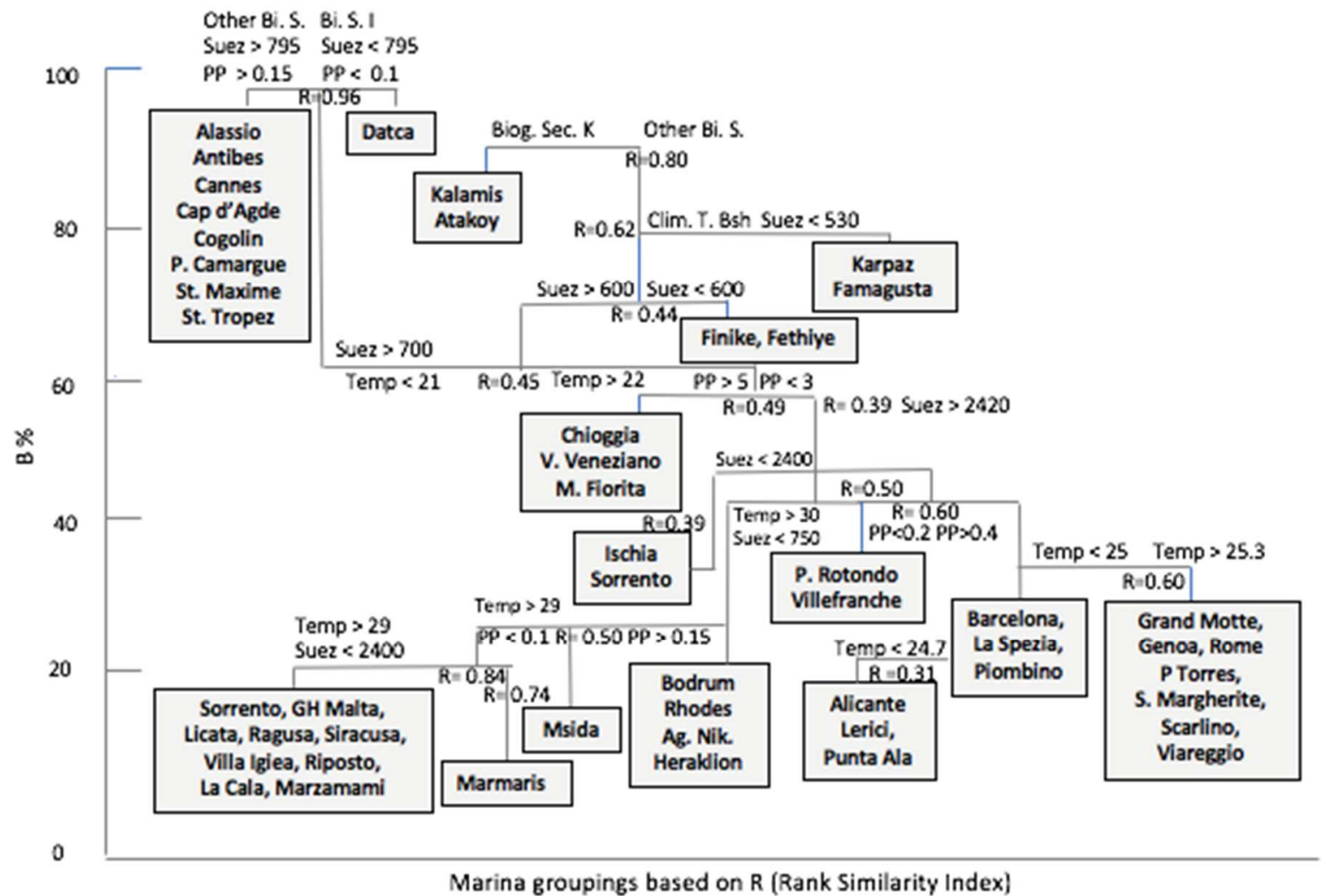




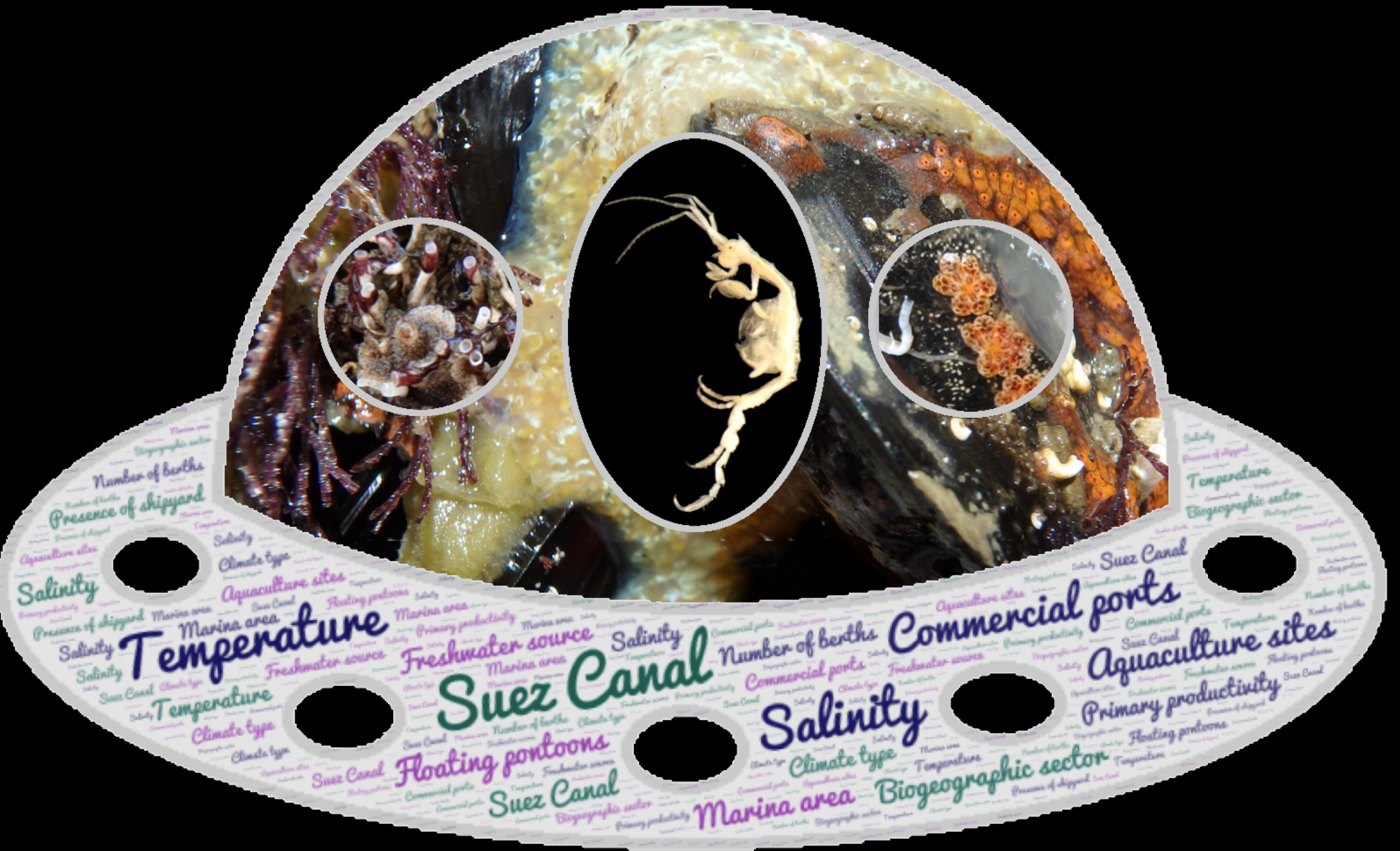

